\title{
FIRM PRODUCTIVITY AND IMPORTING BETWEEN UKRAINE AND CHINA
}

\author{
Goroshko Maryna, \\ Shanghai Finance and Economy University \\ DOI: https://doi.org/10.31435/rsglobal_ijite/31012019/6331
}

\section{ARTICLE INFO}

Received 28 November 2018

Accepted 20 January 2019

Published 31 January 2019

\section{KEYWORDS}

strategic partnership, export,

import,

value of external trade,

bilateral relations,

the complementarity index,

Ukraine,

China. \begin{abstract}
This paper attempts to explore China's economic interest in Ukraine, a country which is in an advantageous geographic location with relation to China. Considering its position in the global map, Ukraine has the potential to become a transit hub for China. This has huge economic repercussions in Ukraine since China is the second most important EU trading partner after USA. Ukraine can thus take advantage of being a unique transit hub for China in the Silk Road. Instrumental background to Ukraine economic relations with China In spite of having a huge market potential, Ukraine did not share an optimistic trade relation with China. The country's unstable political environment along with having investment risks induces China to maintain a cautious approach toward Ukraine. However, due to a positive political relationship between the two countries, Ukraine can play in favour of China's strategy to strengthen the Silk Road Economic Belt. Although this facilitates China's trading relationship with Russia and the EU, the current crisis in Ukraine has become a concern for China since it does not want to play the role of diplomatic intermediary in Ukraine crisis. China chooses its strategic partners usually based on a couple of factors. The country has to be China's neighboring country as it can then become a close economic ally, and also the chosen country has to be large in size as China can use it to develop strategic partnership to fulfill its economic goals. However, Ukraine does not fall under any of the categories and so it fulfills a third category which is also another category that is considered by China. Ukraine shows a great potential for economic development, which is important for China as it needs to establish strong economic ties with the country in order to get benefitted in other areas. Moreover, China is also able to encase the history of friendly relationship that it shares with Ukraine, and also Ukraine's strong geographical position enables China to engage in regional cooperation. Finally, China looks for opportunities of cooperation as this can enhance the strategic relationship between two countries and Ukraine serves such opportunities.
\end{abstract}

Citation: Goroshko Maryna. (2019) Firm Productivity and Importing Between Ukraine and China. International Journal of Innovative Technologies in Economy. 1(21). doi: 10.31435/rsglobal_ijite/31012019/6331

Copyright: (C) 2019 Goroshko Maryna. This is an open-access article distributed under the terms of the Creative Commons Attribution License (CC BY). The use, distribution or reproduction in other forums is permitted, provided the original author(s) or licensor are credited and that the original publication in this journal is cited, in accordance with accepted academic practice. No use, distribution or reproduction is permitted which does not comply with these terms.

Review of relevant literature. The attention of researchers attract various aspects of mutual support, the formation of integration structures, implementation of joint economic projects, but covered in fragments of cooperation with low income, generally defined as a global "periphery". In particular, the following classifications are considered like the Ukrainian-Chinese relations, despite the obvious differences in size of countries and their global impact. For Ukraine, the direction of relations with China is a priority, due to the rapid economic development of the country, which has now become a major player in the Asia-Pacific Region (APR) and is second only to the US economy in the world. In addition, China has excess capital and marked the political influence of the global economic system that in the current situation is of particular relevance.

Important theoretical and practical aspects of strategic partnerships form the basis of studies of domestic and foreign scientists, including Ukrainian scientists Andriychuk B., O. Belarus, Mikhail Belousov, V. Borschevsky V. Verhun, A. Goncharenko, Vladimir Granovsky, OH. DERGACHOV, IA Dolgov, 
MA Nether, I. Zhovkva， O. Zarubinskyi， D. Lukyanenko, Yuri Makogon， M. Malskyy， M. Matsyaha, V. Melnik, A. Mokiy, N. Naumenko, B. Parahonskoho, Y. Pakhomov, Pyrozhkov, S. Pisarenko Alexander Plotnikov, Poltoratskiy A., A. Potekhin, C. Saveliev, A. Sobolev, Alexander Filipenko, M. Fleychuk V. Chaly, S. Cebotaru O. Shnyrkov, L. Yaremko and others. Among the foreign authors who have studied the strategic partnership in the context of the interaction between individual firms should distinguish A. Rodrigo, A. Heusler, H. Luo, J. Shen, B. Barnes, B. Dale, D. Walker, K. and others. However, despite the undeniable achievements of domestic and foreign scientists, the conceptual basis of criteria and approaches to the definition of "strategic partnership" remains poorly understood and on the basis of their analysis of UkrainianChinese relations, this paper can lead to the scientific novelty of the thesis topic.

For the current study, secondary sources are used like various scientific journals that explain the political and economic relationship between China and Ukraine. The purpose is to establish the ground on which China has formed strategic alliance with Ukraine so as to facilitate its own trading relationship with Russia and the EU.

The nature and characteristics of strategic partnership.

According to O.N. Methrota 'the strategic partnership is a new term, which has been popularized in the international relations of the post Cold War period" (Wilkins, 2008, p.359). In general, strategic partnership is formed when the participating countries have common interests rather than shares values. Second, strategic alliance is formed in order to fulfil specific goals and so even countries with negative political relations can enter into strategic partnership provided the countries can offer economic opportunities to each other. In such cases however security issues become a major issue of concern in the context of terrorism, separatism, or religious fundamentalism. Moreover, strategic partnership is rather a informal agreement that allows the countries enough flexibility and autonomy, and this reduces the formal issues common to more orthodox alliances. Strategic partnership is often initiated between two countries where the target country provides economic opportunities to the countries who intend to form strategic alliance. The basic goal remains to fulfil its own objectives of economic expansion beyond its boundaries. Although strategic partnership is bilateral often other countries are included into the alliance. For instance, the strategic partnership between Russia and China also has other partners like India and Iran. It is also not uncommon that strategic alliance can be established between two apparently antagonistic countries like China's relationship with Britain and Sudan. However, such alliances can limit the possibilities for formal expansion and evolution.

Analysis Ukrainean - Chinese relationship according to the criteria at strategic partnership.

Based on the strategic partnership, China entered into trading alliance with Ukraine because of the huge market potential that the latter held. The first reason behind the bilateral relationship is Ukraine's geographical position that makes it an easy transit route for China to deliver oil and gas to the EU countries. Although Ukraine's infrastructural facilities are not well developed that is not considered as a major crisis. The second reason is that Ukraine has signed the Deep and Comprehensive Free Trade Agreement (DCFTA) with EU. For this reason, Ukraine can attract investment from China for manufacturing products specifically for the EU market. Ukraine's proximity to EU is a major reason for Chinese investments in the countries in spite of its high investment risk environment.

\section{Ukraine for China is:}

- A "bridge" into a capacious and financially

reliable European market;

- A market for cheap goods;

- The partner in supplies of the products of the metallurgical complex, the chemical industry, the products of the agro-industrial complex, etc.;

- The partner for personnel development and on-the-job training;

- A "window" to the high-tech and capitalsurplus economy of the European Union;

- A large market with significant purchasing power and consumer needs;

- A territory for the creation of technoparks and high technology development zones;

- A link in the transit chain between Western

Europe and the Asia-Pacific Region.
China for Ukraine is:

- A partner for attracting investments:

- A reliable partner in support of national interests of Ukraine in the international arena (accession to the WTO, the UN peacekeeping operations, etc.): - An advanced partner in the supply of advanced equipment and technologies that can increase the competitiveness of Ukrainian products;

- A partner in the development of entrepreneurial and investment projects in the oil and gas, and coal industries, civil engineering. production of consumer goods, in agro-industrial complex, renewable energy technologies, financial and banking sector, etc.

- A partner in optimizing the structure of exports and improving product quality.

Fig. 1. 
In May 2016, Chinese President Xi Jinping proclaimed that China should become the most innovative country in the world in 2030 and the world leader in the scientific sphere until 2049. State constituents are aware that achieving such ambitious goals can be achieved through more extensive cooperation with representatives of science from other countries, in particular with Ukraine. The leadership of China highly appreciates the level of advanced technologies available at the National Academy of Sciences of Ukraine and notes the fruitfulness of bilateral cooperation in numerous branches of science, technology and industry and states its readiness for its expansion and deepening.

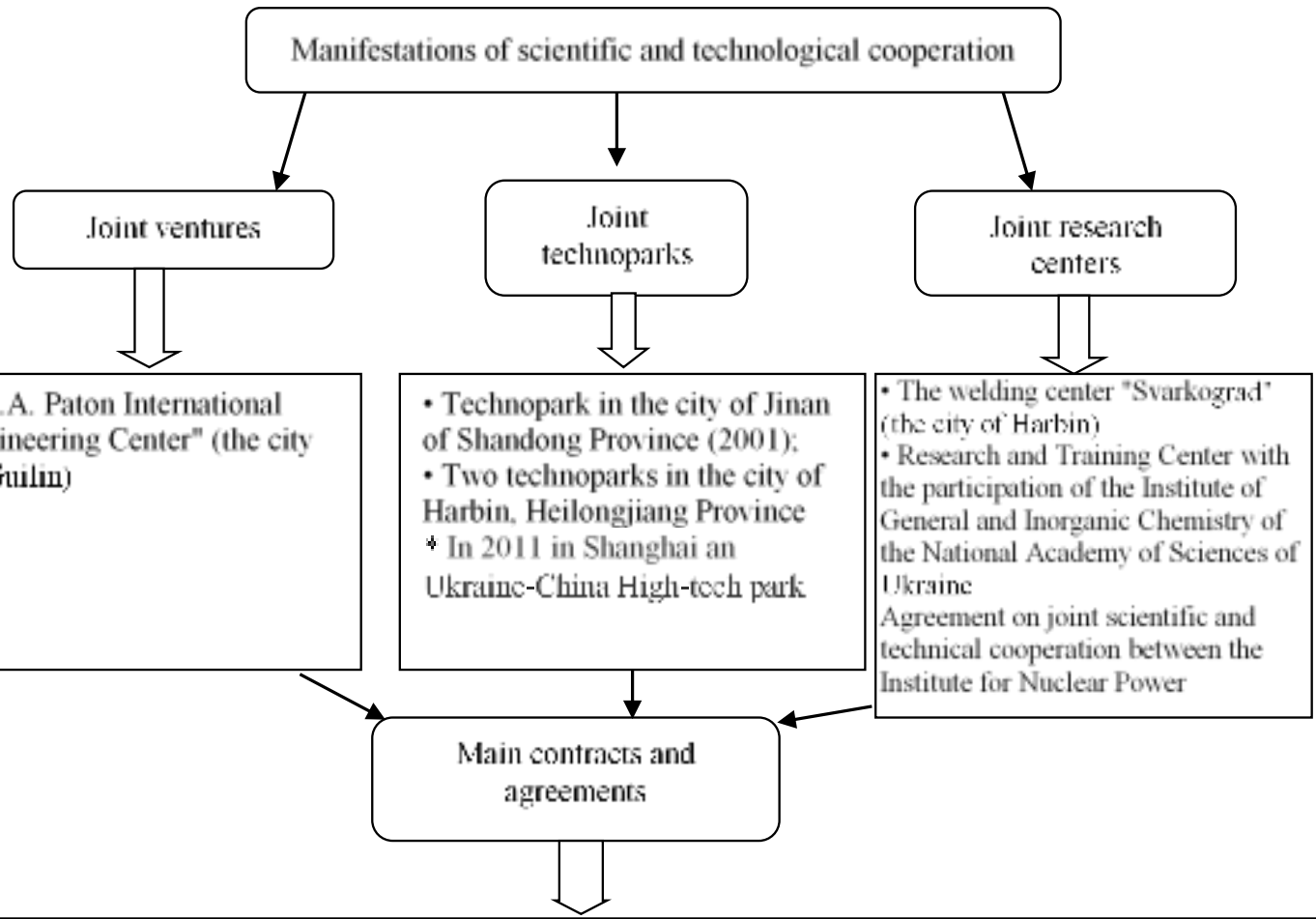

- Agreement between the Government of Ukraine and the Government of the PRC on scientific and technical cooperation (1992);

- Agreement on scientific cooperation between NASU and the Academy of Sciences of the PRC (1992):

- Agreement on the establishment of an intergovernmental Ukrainian-Chinese commission on trade and economic cooperation (1992):

- Protocol on the establishment of the Joint Ukrainian-Chinese Commission for Scientific and Technical Cooperation (1997);

- Agreement on cooperation between the governments of Ukraine and China in the field of intellectual property 12002 );

- Contract between O.K. Antonov ASTC and the Chinese aircraft building corporation AVIC (concerning the development of a supercritical wing for a ('hinese short-haul passenger jet) (2003):

- Cooperation agreement between the Kiev Center for Scientific, Technical and Economic Information and the Jinan Park for Iligh-Tech Cooperation between Ukraine and the PRC (2003):

- Agreement on the establishment of the International Center for Technology Transfer, the Industrial Research and Development Base of the National Academy of Sciences of Ukraine in Jiaxing (Zhejiang Province) (2005);

- Cooperation agreement between the Harbin Center for International Scientific and Technical Transfer and the Kiev Center for Scientific. Technical and Economic Information (2009)

"In 2011 in Shanghai an Ukraine-China I ligh-tech park was founded which is focused on fields of maritime science and technology, biotechnology, new materials, aerospace technologies and renewable energy

* In 2012 an Ukraine-China Centre on transfer of shipbuilding technology has been created in Zhejian by Science and Technology University of Jiansu province and Ukrainian National Shipbilduing University of Mykolaiv.

*Agreement on joint scientific and technical cooperation between the Institute for Nuclear Power Safety Problems of the National Academy of Sciences of Ukraine and Qingdao Xianchu Mechanical Equipment Co. Ltd "(PRC), which was signed on September 25. 2015

*In June 2016 in Harbin the Sino-UkrainianCenter for Scientific and Technical Cooperation was established as a platform for scientific cooperation in different fields, particularly in the field of welding.

Fig. 2. 
Such active scientific activity contributes to the development of scientific and technical cooperation between countries, which is at a high level, as evidenced by the signed contracts; and also joint ventures, research centers and technoparks have been established.

Foreign trade cooperation between Ukraine and China is regulated by the Trade and Economic Cooperation Agreement between Government of Ukraine and Government of the People's Republic of China (1992) that setting of most favorable regime regarding the duties levy for exported and imported goods of both countries as well as taxes and other domestic dues. According to information of the General Customs Administration of China, in January-September 2016 the trade turnover between Ukraine and China amounted to 5188,2 million USD. At the same time, Chinese exports to Ukraine amounted to 3126,3 million USD ( $+24.2 \%$ ), Chinese imports from Ukraine amounted to 2061,9 million USD (-32.0\%). Balance of bilateral trade in favor of China amounted to 1064,4 million USD (Trade and Economic Relations between Ukraine and China, 2012).

\section{The model.}

China imported 380,000 metric tons of corn from Ukraine during May 2015. The total volume of corn exports from Ukraine to China amounted to more than 2.1 million metric tons for the market year that began in October 2014. Among the total corn imports in China it is estimated that Ukraine constitutes of three-fourths for 2014/15. The increasing imports of corn from Ukraine is a strategy by China to reduce its dependence of US, a country which was the biggest corn exporter to China before Ukraine came into the picture (Ukraine is China's Main Corn Supplier, 2015).

The equilibrium value of the complementarity index for the trade by main commodity groups between Ukraine and China in the period from 2008 to 2017

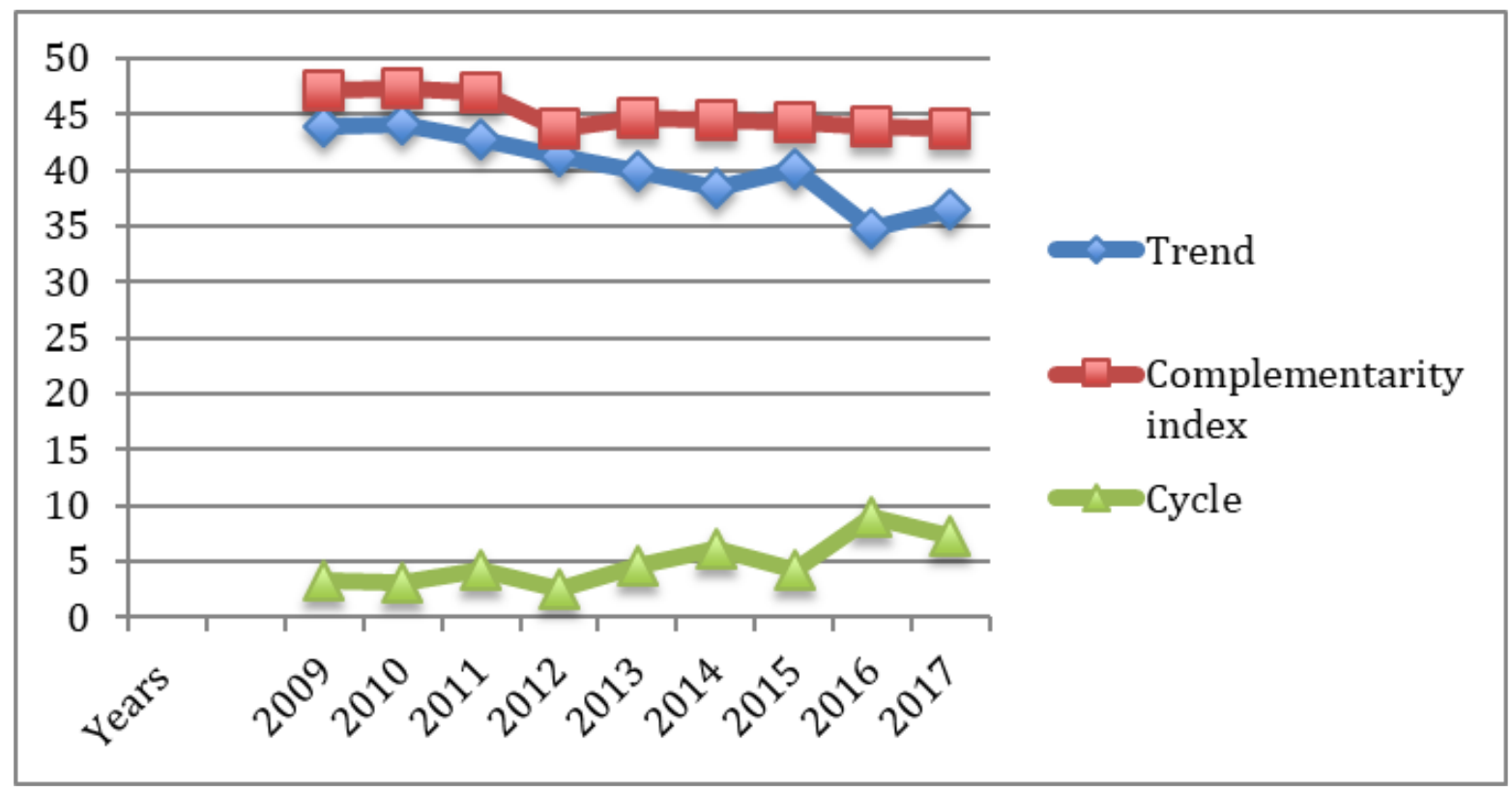

Fig. 3.

Analysis of the exports and imports commodity positions for Ukraine and China testifies to the complementarity of the economic systems of the two countries at the level of $44 \%$ (2017). To identify the most complementary goods in Ukrainian-Chinese trade, we will calculate the complementarity index taking into account the specification of goods. This indicator characterizes the level of mutual complementarity between the supply of certain goods from Ukraine and the demand for imports of the same goods in China. Calculations are carried out according to the formula

$$
T C I_{i j}^{k}=\frac{X_{i}^{k} / X_{i}}{M_{w}^{k} / M_{w}} * \frac{M_{j}^{k} / M_{j}}{M_{w}^{k} / M_{w}}
$$


Table 1. The complementarity index of Ukrainian-Chinese trade taking into account the commodity specification $\left(\mathrm{TCI}_{\mathrm{c}}\right)$

\begin{tabular}{|c|c|c|c|c|c|c|}
\hline Products / Years & 2012 & 2013 & 2014 & 2015 & 2016 & 2017 \\
\hline 72. Iron and steel & 0,003 & 40,70 & 45,98 & 37,77 & 33,88 & 31,43 \\
\hline $\begin{array}{l}\text { 27. Mineral fuels, mineral oils and products of } \\
\text { their distillation }\end{array}$ & 0,33 & 0,31 & 0,24 & 0,10 & 0,10 & 0,12 \\
\hline $\begin{array}{l}\text { 84. Machinery mechanical appliances, nuclear } \\
\text { reactors, boilers; }\end{array}$ & 0,63 & 0,89 & 0,76 & 0,71 & 0,60 & 0,55 \\
\hline $\begin{array}{l}\text { 86. Railway or tramway locomotives, rolling } \\
\text { stock and parts there of; railway or tramway } \\
\text { track fixtures. }\end{array}$ & 27,05 & 24,95 & 39,01 & 14,91 & 24,16 & 53,28 \\
\hline 73. Articles of iron & 22,63 & 23,73 & 14,99 & 11,49 & 8,57 & 11,25 \\
\hline $\begin{array}{l}\text { 85. Electrical machinery and equipment and } \\
\text { parts there of; sound records and repoducers } \\
\text { television... }\end{array}$ & 0,136 & 0,13 & 0,14 & 0,12 & 0,13 & 0,15 \\
\hline 10. Cereals & 103,615 & 102,33 & 82,79 & 34,54 & 82,43 & 74,38 \\
\hline $\begin{array}{l}\text { 28. Inorganic chemicals; organic or iorganic } \\
\text { compounds of precious metals, of rare-earth metals; }\end{array}$ & 6,47 & 8,22 & 5,39 & 5,24 & 3,63 & 3,62 \\
\hline 31. Fertilisers & 23,53 & 25,00 & 17,20 & 10,89 & 13,46 & 6,35 \\
\hline 26. Ores, slag and ash & 0,129 & 0,16 & 0,19 & 0,21 & 0,16 & 0,18 \\
\hline $\begin{array}{l}\text { 90. Optical, photographic, cinematographic, } \\
\text { measuring, checking, precision, medical or surgical }\end{array}$ & 0,036 & 0,04 & 0,04 & 0,04 & 0,04 & 0,04 \\
\hline $\begin{array}{l}\text { 62. Articles of apparel and clothing accessories, } \\
\text { not knitted or crocheted }\end{array}$ & 27,85 & 25,67 & 25,36 & 21,31 & 23,52 & 23,14 \\
\hline $\begin{array}{l}\text { 15. Animal or vegetable fats and oils and their } \\
\text { cleavage products; prepared edible fats; animal... }\end{array}$ & 7,07 & 9,78 & 17,08 & 21,15 & 30,62 & 29,68 \\
\hline 44. Wood and articles of wood; wood charcoal & 1,55 & 1,41 & 1,34 & 1,86 & 1,67 & 1,36 \\
\hline 76. Aluminum and articles there & 0,64 & 0,97 & 1,27 & 1,69 & 1,74 & 2,29 \\
\hline 29. Organic chemicals & 0.131 & 0,08 & 0,07 & 0,05 & 0,06 & 0,08 \\
\hline $\begin{array}{l}\text { 04. Dairy produce; birds eggs; natural honey; } \\
\text { edible products of animal origin, not else where... }\end{array}$ & 12,318 & 7,40 & 5,06 & 12,22 & 8,58 & 7,24 \\
\hline 99. Commodities not elsewhere specified & 0,07 & 0,06 & 0,02 & 3,19 & 1,57 & 0,12 \\
\hline $\begin{array}{l}\text { 48. Paper and paperboard; articles of paper pulp, } \\
\text { of paper or of paperboard }\end{array}$ & 21,43 & 31,32 & 30,62 & 22,94 & 20,27 & 12,99 \\
\hline 39. Plastics and articles thereof & 0,24 & 0,22 & 0,19 & 0,20 & 0,21 & 0,26 \\
\hline 22. Beverages, spirits and vinegar & 11,12 & 15,62 & 10,61 & 4,67 & 3,30 & 3,85 \\
\hline $\begin{array}{l}\text { 25. Salt, sulphur; earths and stone; plastering } \\
\text { materials, lime and cement. }\end{array}$ & 2,66 & 3,60 & 3,51 & 3,06 & 3,04 & 2,24 \\
\hline $\begin{array}{l}\text { 87. Vehicles other than railway or tramway } \\
\text { rolling stock, and parts and accessories there. }\end{array}$ & 0,40 & 0,29 & 0,19 & 0,21 & 0,15 & 0,14 \\
\hline 74. Copper and articles there & 0,03 & 0,04 & 0,05 & 0,05 & 0,04 & 0,05 \\
\hline 02. Meat and edible meat off & 5,49 & 3,70 & 5,20 & 4,02 & 1,74 & 3,13 \\
\hline 38. Miscellaneous chemical products & 0,35 & 0,41 & 0,33 & 0,33 & 0,32 & 0,37 \\
\hline $\begin{array}{l}\text { 94. Furniture; bedding, mattresses, mattress } \\
\text { supports, cushions and similar syffed furnishing }\end{array}$ & 31,24 & 38,62 & 38,64 & 36,57 & 36,12 & 40,79 \\
\hline $\begin{array}{l}\text { 63. Other made-up textile articles; sets; worn } \\
\text { clothing and worn textile articles; rags }\end{array}$ & 88,74 & 94,13 & 99,94 & 107,81 & 115,52 & 115,58 \\
\hline $\begin{array}{l}\text { 12. Oil seeds and oleaginous fruits, miscellaneous } \\
\text { grains, seeds and fruit, industrial of medicinal }\end{array}$ & 8,564 & $\begin{array}{l}10,99 \\
\end{array}$ & 7,83 & 6,76 & 5,81 & 6,77 \\
\hline 52. Cotton & 0,002 & 0,004 & 0,005 & 0,01 & 0,01 & 0,01 \\
\hline
\end{tabular}


Based on the results obtained, we form the clustering of goods according to their complementarity level in 2017.

Table 2. Level of complementarity of goods in 2017

\begin{tabular}{|l|l|}
\hline Complementarity level & Goods \\
\hline Very high & $\begin{array}{l}\text { Iron and steel; Railway or tramway locomotives; rolling stock and parts there of; } \\
\text { railway or tramway track fixtures; Cereals; Articles of apparel and clothing } \\
\text { accessories, not knitted or crocheted; Animal or vegetable fats and oils and their } \\
\text { cleavage products; prepared edible fats; Furniture; bedding, matresses, mattress } \\
\text { suports, cushions and similar syffed furnishing; Other made-up textile articles; } \\
\text { sets; worn clothing and worn textile articles; rags }\end{array}$ \\
\hline High & $\begin{array}{l}\text { Articles of iron; Fertilisers; Paper and paperboard; articles of paper pulp, of } \\
\text { paper or of paperboard; Oil seeds and oleaginous fruits, miscellaneous grains, } \\
\text { seeds and fruit, industrial of medicinal; }\end{array}$ \\
\hline Moderate & $\begin{array}{l}\text { Inorganic chemicals; organic or iorganic compounds of precious metals, of rare- } \\
\text { earth metals; Wood and articles of wood; wood charcoal; Aluminum and articles } \\
\text { there; Dairy produce; birds eggs; natural honey; edible products of animal origin; } \\
\text { Beverages, spirits and vinegar; Salt, sulphur; earths and stone; plastering } \\
\text { materials, lime and cement; Meat and edible meat off; }\end{array}$ \\
\hline $\begin{array}{l}\text { Mineral fuels, mineral oils and products of their distillation; Machinery mechanical } \\
\text { appliances, nuclear reactors, boilers; Electrical machinery and equipment and parts } \\
\text { there of; sound records and repoducers television; Ores, slag and ash; Optical, } \\
\text { photographic, cinematographic, measuring, checking, precision, medical or surgical; } \\
\text { Organic chemicals; Commodities not elsewhere specified; Plastics and articles } \\
\text { thereof; Vehicles other than railway or tramway rolling stock, and parts and } \\
\text { accessories there; Copper and articles there; Miscellaneous chemical products; } \\
\text { Cotton }\end{array}$ \\
\hline
\end{tabular}

The most noticeable complementarity is observed in such commodity groups as: railway or tramway locomotives, road equipment; ore, slags and ashes; fats and oils of animal or vegetable origin; and ferrous metals. Somewhat lower complementarity is in such goods as salt, sulfur, plastering materials, cement; fertilizers; inorganic chemistry products; wood and wood products; articles of ferrous metals; copper and copper products, for which Ukraine has a competitive advantage. Goods with a high level of complementarity during the last six years show a rather unstable dynamics - from a sharp increase to a deterioration in the value this is directly related to the production capabilities of the partner country.

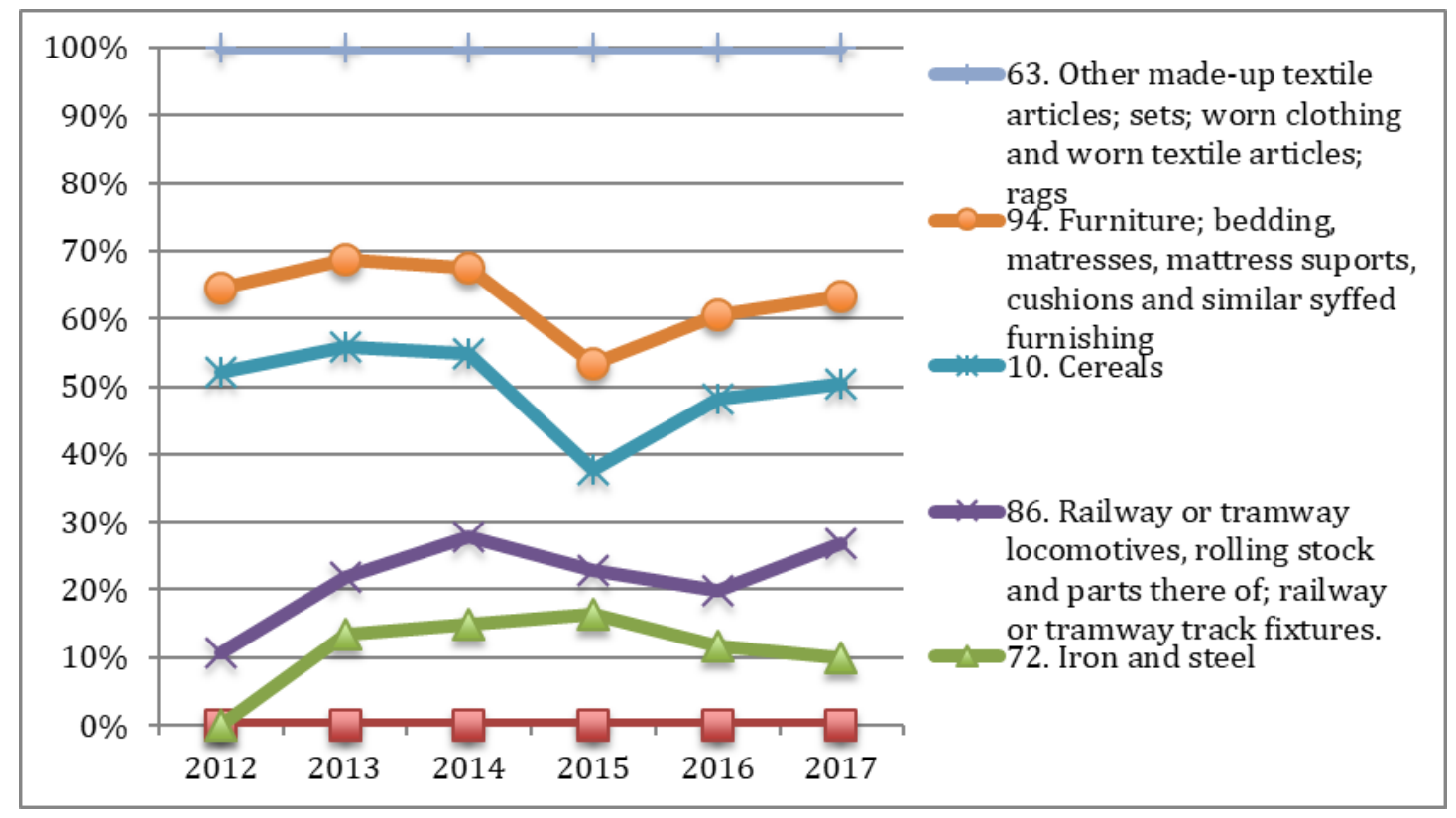

Fig. 4. Dynamics of trade in commodities with a high level of complementarity in the period from 2012 to 2017 
Conclusions. The trading relationship between China and Ukraine has seen a slow by steady growth. Ukraine's agricultural sector is one principle source of trading volume between the two countries. It is very clear that China has various strategic advantages by maintaining a bilateral trading relationship with Ukraine. Ukraine can become the road to connect to China and its trading partner.

\section{REFERENCES}

1. Strategic cultures of the USA and Europe/ Davydov/USA:Canada - 2006. - № 3. - P. 48-69.

2. Principles of Strategic Partnership: [transcript of the round table] // Politics and time. - 2001. - № 3. - P. 40-52.

3. How to live, differing, but in harmony /Perepilycia// Politics and time. -2002 . - № 4. - P. 50-64.

4. Jovkva I. Strategic partnership of Ukraine. Theory and practice/ Gorbulina P. - K.:DP "NVC" Euroatlanticinform", 2006. - P.156

5. Malskiy M. The theory of international relations/ Malskiy M., Maciah M. - Lviv: Lviv National University. Ivan Franko, 2012. - P.392

6. Ribalt A. Partnership is a support in difficult times, says Foreign Minister of Poland Włodzimierz Cimoszewicz [Electronic resource] / Ribalt A. // Day. - 2017. - № 224. - Access mode http://www.day.kiev.ua.

7. Ukraine and Poland are on the verge of a new millennium [Electronic resource] // Day. - 2009. - № 46. Access mode http://www.day.kiev.ua.

8. Alimov O. Strategic partnership and energy security of the state / Alimov O., Mikitenko V. // Bulletin of the National Academy of Sciences of Ukraine: Monthly. general science and community-political. journal K.: Academiperiodica, 2004. - No. 9. - P. 17-22.

9. Svjezhentseva Y. What is a partnership and how to measure it: the conceptual and operational aspects of the social phenomenon / Yu Svjezhentseva // Sociology: theory, methods, marketing. - 2006. - No. 2. - P. 133-148.

10. Lisitsin E. Strategic partnership - the notion of modern / E. Lisitsin // Veche. - 1999. - No. 2 (83). - P. 32-43.

11. Geisler E. Intersector technology cooperation: hard myth, soft facts / Eliezer Geisler // Technovation. 1997. - № 17 (6). - P. 309-320.

12. https://www.business.ua/vlast/item/3175-sutinkova-zona 02.04.2018 journal Buisness in Ukraine.

13. https://agropolit.com/spetsproekty/379-mij-zahodom-i-shodom-yaka-rol-ukrayini-na-shovkovomu-shlyahu Between the West and the East: What is the role of Ukraine on the Silk Road

14. Ukraine - Chinese partnership - Magokin Z.Y. - paper 